\title{
A New Visible Spectrophotometric Approach for Mutual Determination of Amoxicillin and Metoclopramide Hydrochloride in Pharmaceuticals After Cloud Point Extraction
}

\author{
Zuhair A-A. Khammas", Hawraa M. Abdulkareem \\ Department of Chemistry, College of Science for Women, University of Baghdad, Jadiyriah, Baghdad, Iraq \\ Email address: \\ saifkhammas@gmail.com (Z. A-A. Khammas), hawraa197977@yahoo.com (H. M. Abdulkareem) \\ ${ }^{*}$ Corresponding author
}

\section{To cite this article:}

Zuhair A-A. Khammas, Hawraa M. Abdulkareem. A New Visible Spectrophotometric Approach for Mutual Determination of Amoxicillin and Metoclopramide Hydrochloride in Pharmaceuticals After Cloud Point Extraction. Science Journal of Analytical Chemistry.

Vol. 4, No. 5, 2016, pp. 66-76. doi: 10.11648/j.sjac.20160405.12

Received: September 8, 2016; Accepted: September 26, 2016; Published: October 18, 2016

\begin{abstract}
A new approach has been developed and validated for the mutual determination of the drugs of amoxicillin (AMX) and Metoclopramide hydrochloride $(\mathrm{MCP}$. $\mathrm{HCl}$ ) in pharmaceuticals. The method is based on the reaction of diazotized Metoclopramide with amoxicillin in an alkaline medium to form an intense orange water-soluble product which can be easily extracted from micelles of a non-ionic surfactant (Triton X-114) and both drugs measured sequentially at the same absorption maximum of $479 \mathrm{~nm}$. The optimization of all experimental variables was individually performed to obtain high extraction efficiency for both target medicaments. Under the optimized conditions, Beer's law was obeyed in the concentration range of 0.3-3.0 $\mu \mathrm{g} \mathrm{mL}^{-1}(\mathrm{r}=0.9995)$ for both AMX and MCP. The enrichment factors were found to 214 and 90.85 fold for AMX and MCP, led to obtaining the detection limits of 0.083 and $0.098 \mu \mathrm{g} \mathrm{mL}^{-1}$, and a superb sensitivity in terms of the molar absorptivity of $2.35 \times 10^{5}$ and $2.25 \times 10^{5} \mathrm{~L} \cdot \mathrm{mol}^{-1} . \mathrm{cm}^{-1}$, respectively. The mean recovery percentage of $97.77 \pm 1.72 \%$ (in AMX capsule) and $98.20 \pm 1.95$ (in MCP ampoule); the precision (RSD \%) ranged between 2.35-10.8\% and 0.20-3.43\% were obtained for AMX and MCP respectively. The proposed method was validated and applied for determination of AMX and MCP in various samples of the pharmaceutical preparations.
\end{abstract}

Keywords: Amoxicillin, Metoclopramide Hydrochloride, Diazotization Coupling Reaction, Cloud Poin Extraction, Visible Spectrophotometry

\section{Introduction}

The chemical analysis of two analytes mutually in one reaction system with the same extraction and detection method has become a unique and attractive theme in contemporary analytical chemistry. This type of chemical analysis is in itself economic in terms of reducing analyst effort, time and simplifies the analytical procedures as well as reduces the costs involved in the use of chemicals in the analytical methods when determining two or more of the target analytes. These features are embodied by our recent published papers [1-3] which encouraged us and other researchers in our universities to be engaged in the development of new analytical methods based on other reactions systems that make us believe that this work will open new horizons in analytical chemistry. We have adopted in our preceding works, complex formation reactions in which the ligand and metal ions have been estimated in the same reaction system. We relied in this work on the diazotization -coupling reactions between two drugs to form a chromogenic product, namely amoxicillin (AMX) and metoclopramide hydrochloride (MCP.HCl), with a view to extract them via the cloud point extraction (CPE) and their mutual determination spectrophotometrically. The main reason for selecting the diazotization-coupling reaction system in this research work goes back to the increasing of its popularity in the estimation 
of the drugs spectrophotometrically.

Amoxicillin (Figure 1a) chemically known as 6(p-hydroxy-alpha-aminophenyl acetamido) penicillanic acid is commonly used as an antibacterial drug in the treatment of infections caused by gram-positive gram-negative bacteria [4]. whilst the metoclopramide hydrochloride (Figure 1b),4-amino-5-chloro- [2- (diethylamino)ethyl]-2 methoxybenzamide $\mathrm{HCl}$, is widely used in prevention and relief of nausea and vomiting as well as in combination with chemotherapy, where drugs such as cisplatin, and other cytotoxic agents, are highly emetic [5-6]. Human pharmacokinetic interactions of these drugs have not yet documented, but the clinicians advise patients not to use these drugs together because this reduces the action of each drug as well as AMX may induce diarrhoea in some patients [7]. Due to their wide use for the medical and clinical treatments, it is found that there are enormous research publications been dedicated to estimating these drugs in the pharmaceuticals and to a<smiles>CC1(C)S[C@@H]2[C@H](NC(=O)[C@@H](N)c3ccc(O)cc3)C(=O)N2[C@H]1C(=O)O</smiles>

(a)

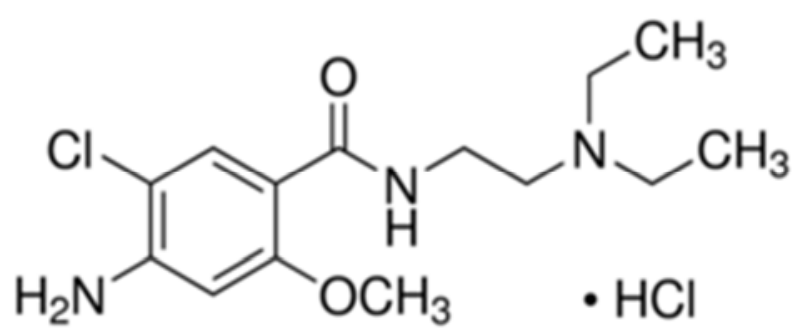

(b)

Figure 1. Chemical structure of (a) Amoxicillin $\left(\mathrm{C}_{16} \mathrm{H}_{25} \mathrm{~N}_{3} \mathrm{O}_{8} \mathrm{~S}\right.$; M.wt. $419.45 \mathrm{~g}$ $\left.\mathrm{mol}^{-1}\right)$ and (b) Metoclopramide hydrochloride $\left(\mathrm{C}_{14} \mathrm{H}_{23} \mathrm{Cl}_{2} \mathrm{~N}_{3} \mathrm{O}_{2} . \mathrm{HCl}\right.$; M.wt.354.3 $\mathrm{g} \mathrm{mol}^{-1}$ ).

little in bio-samples using different instrumental techniques. Spectrophotometric assay of AMX and MCP.HCl individually in pure or dosage forms were occupied the wide attentions among the reported methods. Most of these methods were adopted for the determination of these drugs using the azo-coupling reaction with various chemical reagents such as benzocaine [8], o-nitrophenol [9], p-nitrophenol [10], o-nitroaniline [11], p-amino benzoic acid and procain [12], sulphanilic acid [13] for AMX drug, and dibenzoyl methane [14] aniline [15], benzoylacetone [16], imipramine hydrochloride [17], p-dimethylaminocinnamaldehyde [18] phenol [19],8-hydroxyquinoline [20],diphenylamine [21], 2, 5 dimethoxyaniline [22] doxycycline hyclate [23], phenoxide
[24] for MCP drug. Although these methods have adequate sensitivity, but they are not devoid of matrix interferences, which may be caused by certain medications additives present in pharmaceuticals for perhaps through their involvement in the diazotization coupling reaction. Therefore, the elimination of the interfering compounds from drug solution before its measurement is a must. Recently, cloud point extraction-spectrophotometric method has received a remarkable attention in quantifying many of the organic compounds of medicinal significance to resolve this dilemma [25-28]. These methods mostly depend on converting the drug compound into chelate or highly colored derivative compounds that can be extracted by using cloud point extraction, and then measured colorimetrically.

The aim at the current work is directed towards designing a new approach to the analyzing the two drugs (AMX and MCP) mutually in the same reaction system by adopting the diazotization coupling reaction, in the first attempt to determine both drugs together by the same analytical procedure in the pharmaceutical dosage forms. Since there are no reports on extracting these drugs using the CPE methodology, so the current method is founded on the diazotized $\mathrm{MCP}$ via the aromatic amino group that exists on $\mathrm{MCP}$ with nitrous acid $\left(\mathrm{NaNO}_{2} / \mathrm{HCl}\right)$ and diazonium salt thus formed and coupled with AMX drug to form an azo dye product which can easily be extracted into micelles of non-ionic surfactant which subsequently, the AMX drug first determined, and then MCP was back-determined colorimetrically at the same absorption maximum but with slight differences in the optimum experimental conditions for both drugs.

\section{Materials and Methods}

\subsection{Apparatus}

The main instrument employed in this work is a Shimadzu double-beam UV-Vis Spectrophotometer model UV-1800 (Kyoto, Japan) equipped with 5-mm optical path cell for scanning the absorption spectrum of the resulting colored product beside the absorbance measurements of the two target drugs under study. Thermostatic water bath model WNB7-45 Experts (England) is used throughout the CPE experiments. For solution $\mathrm{pH}$ measurements, a portable $\mathrm{pH} / \mathrm{mV} / \mathrm{C}$ meter $\mathrm{HI}$ 83141 (HANNA, Romania) is used.

\subsection{Reagents and Materials}

The chemicals used for this work are of high purity and used as received. Doubly distilled water was used in the preparation of all solutions and for final rinsing of glass wares. A pure grade $(95.5 \%)$ of amoxicillin trihydrate (AMX) was obtained from Sigma Aldrich (USA). A stock solution of 1000 $\mu \mathrm{g} \mathrm{mL} L^{-1}$ (or $0.0020 \mathrm{M}$ ) for the drug AMX was prepared by dissolving $0.1000 \mathrm{~g}$ in minimum amount of water and diluted to mark with water in a $100 \mathrm{~mL}$ volumetric flask. This solution was transferred to brown bottle and stored in the refrigerator. The working solutions were daily prepared by appropriate 
dilutions in water. A 1.0 M of $\mathrm{HCl}(\mathrm{BDH}, \mathrm{UK})$ was prepared from concentrated solution $(12.1 \mathrm{M})$ by transferring $20.66 \mathrm{~mL}$ into $250 \mathrm{~mL}$ volumetric flask and diluted to mark with water. An amount of $5 \mathrm{mM}$ diazotized metoclopramide hydrochloride $(95.5 \%$, Sigma, USA) solution was daily prepared by dissolving $0.1772 \mathrm{~g}$ of $\mathrm{MCP}$ in a minimum volume of distilled water, and then an amount of $3 \mathrm{~mL}$ of $\mathrm{HCl}$ $(1.0 \mathrm{M})$ was added with stirring at $5^{\circ} \mathrm{C}$ in ice bath. After $5 \mathrm{~min}$, a $0.0345 \mathrm{~g}$ of sodium nitrite (Sigma-Aldrich, USA) was added to the mixture while keeping in ice bath and shaking well for 5 min and the solution was made up to the mark in a $100 \mathrm{~mL}$ volumetric flask with water. An amount of $0.5 \mathrm{M}$ of sodium hydroxide $(\mathrm{BDH})$, sodium carbonate $(\mathrm{BDH})$ and potassium hydroxide (Riedel De-Haenag,Germany) was prepared by dissolving an appropriate amount in water. An amount of 0.5 $\mathrm{M}$ ammonia (BDH, England) solution was prepared from from concentrated solution $(13.4 \mathrm{M})$ by transferring $3.73 \mathrm{~mL}$ into $100 \mathrm{~mL}$ volumetric flask and diluted to mark with water. Triton X-114 (purity >99.9\%), was purchased from AMRESCO LLC (Solon, USA). A 10\% (v/v) of Triton X-114 was prepared by diluting $10 \mathrm{~mL}$ with water in a $100 \mathrm{~mL}$ volumetric flask.

\subsection{Recommended CPE Procedure for AMX Drug}

In $10 \mathrm{~mL}$ volumetric flasks, an amount of AMX standard or sample solutions to the range of $0.3-3.0 \mu \mathrm{g} \mathrm{mL}^{-1}, 0.18 \mathrm{~mL}$ of $0.5 \mathrm{mM}$ of diazotized $\mathrm{MCP}$ and $0.06 \mathrm{~mL}$ of $0.5 \mathrm{M} \mathrm{Na}_{2} \mathrm{CO}_{3}$ were added. After the formation of an orange azo dye product, $1.0 \mathrm{~mL}$ of $10 \%$ Triton $\mathrm{X}-114$ was added, mixed well and diluted to mark with water. The content of each flask was transferred into a $10 \mathrm{~mL}$ centrifuging tubes and kept in the thermostatic bath at $60^{\circ} \mathrm{C}$ for $25 \mathrm{~min}$. Separation of the phases was conducted by centrifugation at $3500 \mathrm{rpm}$ for $20 \mathrm{~min}$. The aqueous phase was easily removed by pipette. The surfactant-rich phase that contains the colored product was dissolved in $1.0 \mathrm{~mL}$ ethanol and the absorbance of the product measured at $479 \mathrm{~nm}$ against a reagent blank prepared under similar conditions. The remaining AMX in aqueous solution was determined by traditional spectrophotometry at $\lambda_{\max }$ of $274 \mathrm{~nm}$ in order to determine the distribution ratio (D) and extraction efficiency $(\% \mathrm{E})$.

\subsection{Recommended CPE Procedure for MCP Drug}

In $10 \mathrm{~mL}$ volumetric flasks, an amount of diazotized MCP standard or sample solutions to the range of $0.3-3.0 \mu \mathrm{g} \mathrm{mL}^{-1}$, $0.08 \mathrm{~mL}$ of $1.0 \mathrm{mM}$ of $\mathrm{AMX}$ and $0.02 \mathrm{~mL}$ of $0.5 \mathrm{M} \mathrm{Na}_{2} \mathrm{CO}_{3}$ were added. After the formation of an orange azo dye product, $0.6 \mathrm{~mL}$ of $10 \%$ Triton X-114 was added, mixed well and diluted to mark with water. The content of each flask was transferred into a $10 \mathrm{~mL}$ centrifuging tubes and kept in the thermostatic bath at $50^{\circ} \mathrm{C}$ for $20 \mathrm{~min}$, and then the same steps were followed as in recommended CPE procedure for AMX. The remaining MCP in aqueous solution was determined by traditional spectrophotometry at $\lambda_{\max }$ of $272 \mathrm{~nm}$ in order to determine the distribution ratio (D) and extraction efficiency $(\% \mathrm{E})$.

\subsection{Preparation of Pharmaceutical Samples}

Two types of pharmaceuticals for amoxicillin namely capsules and vials were obtained from the drugstores in Baghdad as described in Table 9. The powder of ten capsules or vials were mixed, homogenized, and the content of one capsule $(0.6077 \mathrm{~g})$ which equivalent to $500 \mathrm{mg}$ of active drug was dissolved in sufficient amount of water with continuous shaking and filtered. The filtrate solution was transferred into a $100 \mathrm{~mL}$ volumetric flask and diluted to mark with water. This solution contains $5000 \mu \mathrm{g} \mathrm{mL}^{-1}$ of AMX from which 100 $\mu \mathrm{g} \mathrm{mL}^{-1}$ was prepared by dilution. $10 \mathrm{~mL}$ containing different concentrations of the prepared sample solution were transferred to centrifugal tubes and each solution followed the recommended CPE procedure for AMX and the content of drug was measured spectrophotometrically at $\lambda_{\max }$ of $479 \mathrm{~nm}$ for five repeated measurements. Three selected medicaments from different producers in the form of ampoules containing $10 \mathrm{mg}$ per $2 \mathrm{~mL}$ of active $\mathrm{MCP} . \mathrm{HCl}$ were analysized via the direct dilution of the ampoules with water and subjected to recommended CPE procedure for MCP and the content of drug was measured spectrohotometrically at $\lambda_{\max }$ of $479 \mathrm{~nm}$ for five repeated measurements.

\subsection{Statistical Analysis}

Minitab version 17 (Minitab Inc., State College, PA, USA) (29) and Excel 2010 (Microsoft Office ${ }^{\circledR}$ ) were employed to carry out all statistical calculations such as regression and correlation analysis, ANOVA and significance tests.

\section{Results and Discussion}

\subsection{Absorption Spectra}

In an attempt to ascertain the occurrence of reaction between two drugs in the reaction system, certain amounts of standard solution of AMX and diazotized MCP were mixed in the presence of an alkali medium; an intense orange product was immediately formed showing an absorption maximum at $479 \mathrm{~nm}$ (Figure 2A) which was adopted in the optimization conditions of CPE for the two drugs. The absorption spectrum of the azo dye product formed was also recorded against the corresponding reagent blank between 270 to $1100 \mathrm{~nm}$ after obtaining optimum conditions according to the recommended CPE procedure using a Shimadzu model UV-1800 equipped with $1.0-\mathrm{cm}$ quartz cell. Figure $2 \mathrm{~B}$ shows the absorption spectra of azo dye product and the individual pure drugs solutions. It was observed that the absorption maximum of the colored product solution containing $2.24 \times 10^{-5} \mathrm{M}$ of AMX and $4.50 \times 10^{-5} \mathrm{M}$ of diazotized MCP in $1.0 \mathrm{~mL}$ of $10 \% \mathrm{TX}-114$ occurred again at $479 \mathrm{~nm}$, giving the molar absorptivities of $2.35 \times 10^{5}$ and $2.25 \times 10^{5} \mathrm{~L}_{\mathrm{mol}}{ }^{-1} . \mathrm{cm}^{-1}$ for AMX and MCP drugs respectively. Whilst the individual pure AMX and MCP solutions display absorption maximum at 274 and 272 for AMX and MCP drugs respectively. Thus, the wavelength maximum at $479 \mathrm{~nm}$ for the AMX-MCP azo dye product was used throughout this study for micro amounts 
determination of both drugs.

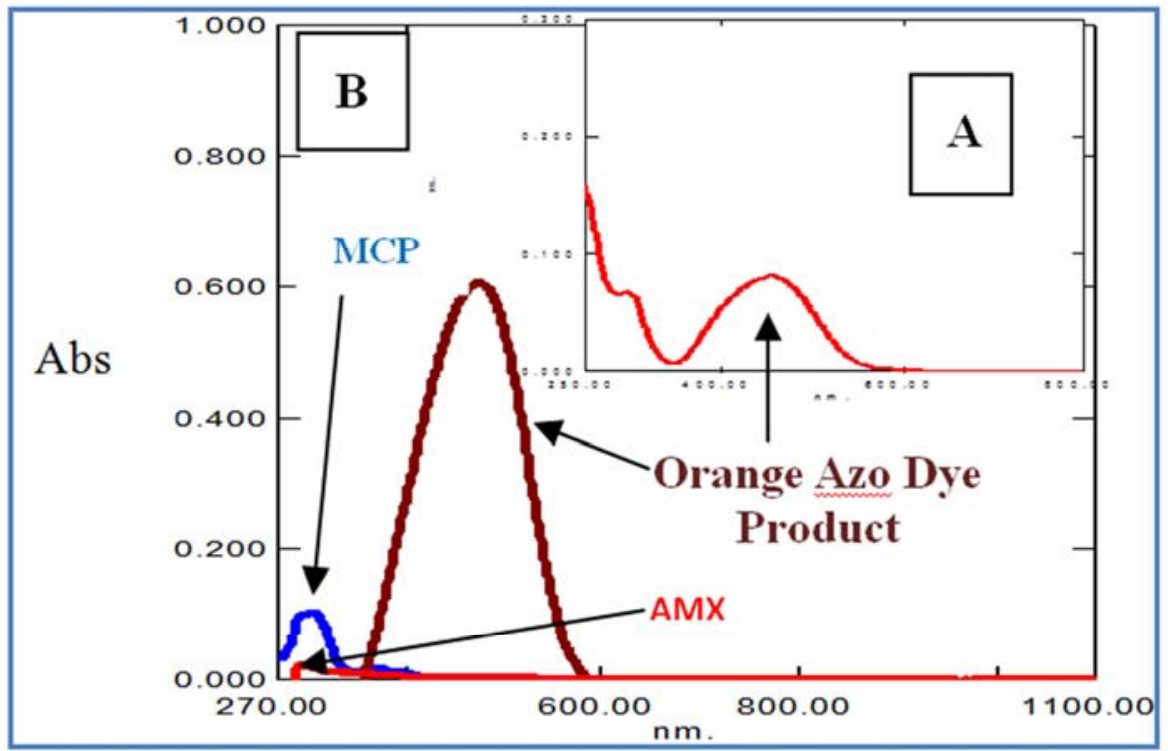

Figure 2. Absorption spectra of azo dye product (A) before CPE and (B) $2.24 \times 10^{-5} \mathrm{M}$ (approx.1.0 $\mu \mathrm{g} \mathrm{mL}^{-1}$ ) of AMX or $2.5 \times 10^{-5} \mathrm{M}\left(\right.$ approx $0.9 \mu \mathrm{g} m L^{-1}$ ) of MCP treated according to recommended CPE.

\subsection{Optimization of CPE Methodology}

A group of experiments has been conducted to study the effect of several variables that affect the extraction efficiency of the CPE and maximize the sensitivity of the detection system for both drugs under study using a classical optimization. The variables such as the concentration of alkaline medium, concentration of each reagent, Triton X-114 amount, equilibration temperature and incubation time. It was previously reported that $\mathrm{HCl}$ was more satisfactory acid compared with other acids such $\mathrm{HNO}_{3}, \mathrm{H}_{2} \mathrm{SO}_{4}, \mathrm{H}_{3} \mathrm{PO}_{4}$, and $\mathrm{CH}_{3} \mathrm{COOH}$ for diazotization reaction of MCP [30] and 3.0 $\mathrm{mL}$ of $1.0 \mathrm{M} \mathrm{HCl}$ was found necessary for complete diazotization of this drug [31-32].

\subsubsection{The Effect of Alkaline Medium}

It was found that the coupling reaction between the drug AMX and diazotized MCP formed in alkaline medium [31]. Consequently, few of the alkaline solutions were tested such as $\mathrm{NaOH}, \mathrm{KOH}, \mathrm{NH}_{4} \mathrm{OH}$ and $\mathrm{Na}_{2} \mathrm{CO}_{3}$ in two series of the separated experiments by taking $10 \mathrm{~mL}$ solution containing $1.0 \mu \mathrm{g} \mathrm{mL}^{-1}$ of AMX and $1 \times 0^{-4} \mathrm{M}$ of diazotized MCP, or 0.88 $\mu \mathrm{g} \mathrm{mL} \mathrm{mL}^{-1}$ diazotized $\mathrm{MCP}$ and $7.15 \times 10^{-6} \mathrm{M}$ AMX, then $3.0 \times 10^{-3} \mathrm{M}$ of alkaline solution and $0.5 \% \mathrm{TX}-114$ were added to each solution. The cloud point extraction was conducted at $65^{\circ} \mathrm{C}$ at $20 \mathrm{~min}$. The results summarized in Table 1 revealed that sodium carbonate was the best alkaline medium for azo coupling reaction between the two drugs used in all subsequent experiments. The effect of different volumes of $0.5 \mathrm{M} \mathrm{Na}_{2} \mathrm{CO}_{3}$ was investigated by varying its volume between $(0.01-0.1 \mathrm{~mL})$ keeping other parameters constant. The results are depicted in Figure 3. It found that the best extraction efficiency for the azo dye product was obtained with 0.06 and $0.02 \mathrm{~mL}$ of $0.5 \mathrm{M} \mathrm{Na}_{2} \mathrm{CO}_{3}$ which equivalent to $3.0 \times 10^{-3} \mathrm{M}$ and $1.0 \times 10^{-3} \mathrm{M} \mathrm{Na}_{2} \mathrm{CO}_{3}$ for the determination of
AMX and MCP respectively, from which they were chosen as optimal in the next experiments.

Table 1. Effect of type of alkaline media.

\begin{tabular}{lll}
\hline $\begin{array}{l}\text { Type of alkaline medium } \\
\mathbf{0 . 6} \mathbf{~ m L} \text { of } \mathbf{0 . 5} \mathbf{M} \text { in } \mathbf{1 0} \mathbf{~ m L} \text { solution }\end{array}$ & $\begin{array}{l}\text { Measured at } \\
\text { Wavelength }(\mathbf{n m})\end{array}$ & Absorbance \\
\hline $\mathrm{NaOH}$ & 471 & 0.135 \\
$\mathrm{KOH}$ & 484 & 0.108 \\
$\mathrm{NH}_{4} \mathrm{OH}$ & 397 & 0.196 \\
$\mathrm{Na}_{2} \mathrm{CO}_{3}$ & 479 & 0.204 \\
\hline
\end{tabular}

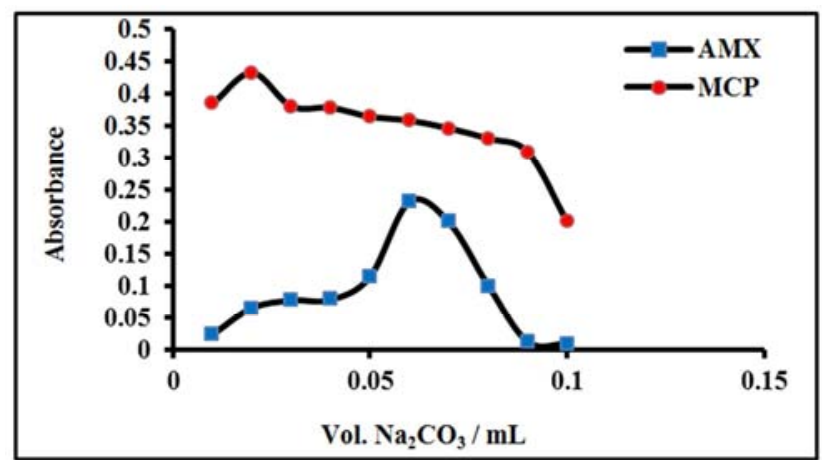

Figure 3. Effect of volume of $0.5 \mathrm{M} \mathrm{Na}_{2} \mathrm{CO}_{3}$ on absorbance and extractability of azo dye product. [Conditions: For AMX: $1.0 \mu \mathrm{g} \mathrm{mL} \mathrm{L}^{-1}$, diazotized MCP; $1.0 \times 10^{-4} \mathrm{M}, \mathrm{TX}-114 ; 0.5 \%, C P T ; 65^{\circ} \mathrm{C}$ and $20 \mathrm{~min}$ incubation time. For $\mathrm{MCP}$; $0.88 \mu \mathrm{g} \mathrm{mL} \mathrm{L}^{-1}, A M X ; 7.15 \times 10^{-6} \mathrm{M}, 0.5 \% \mathrm{TX}-114, \mathrm{CPT} ; 65^{\circ} \mathrm{C}$ and $20 \mathrm{~min}$ incubation time].

\subsubsection{Effect of the Reagents Concentration}

The effect of different concentrations of diazotized MCP on the formation the azo dye product and extraction efficiency of $1.0 \mu \mathrm{g} \mathrm{mL}^{-1}$ of AMX was conducted by varying the volume from 0.02 to $2.00 \mathrm{~mL}$ of $5 \mathrm{mM}$ of diazotized MCP, while the concentration of AMX which affect the extraction of $0.88 \mu \mathrm{g}$ 
$\mathrm{mL}^{-1} \mathrm{MCP}$ drug as the diazotized form was carried out by varying the volume from 0.01 to $0.1 \mathrm{~mL}$ of $1.1 \mathrm{mM}$ of AMX and keeping other conditions constant. Figure 4 displays that the optimum volume of $5 \mathrm{mM}$ diazotized MCP) was of 0.18 $\mathrm{mL}\left(32 \mu \mathrm{g} \mathrm{mL}^{-1}\right)$ and $0.08 \mathrm{~mL}$ of $1.1 \times 10^{-3} \mathrm{M}$ AMX $(4 \mu \mathrm{g}$ $\mathrm{mL}^{-1}$ ) were sufficient to give maximum absorbance, high stability the azo dyes and subsequently the best extraction efficiency for the determination of AMX and MCP drugs in the reaction system. At lower or higher concentrations of each reagent, less intensely colored product was observed so any excessive amount of reagent was not necessary. Therefore, $0.18 \mathrm{~mL}$ of $5 \mathrm{mM}$ diazotized MCP and $0.08 \mathrm{~mL}$ of $1.1 \times 10^{-3} \mathrm{M}$ of AMX in $10 \mathrm{~mL}$ solution were used for further experiments.

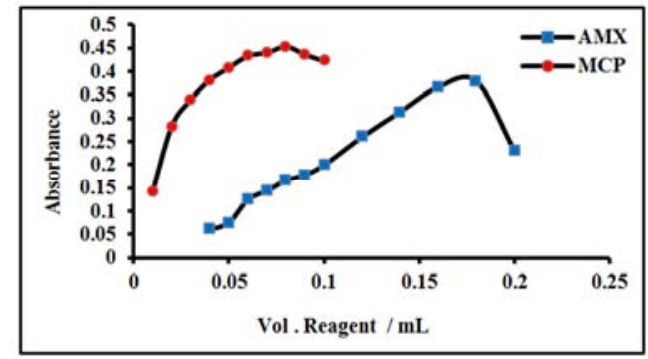

Figure 4. Effect of the reagents concentration on absorbance and extractability of azo dye product [Conditions: For $\mathrm{AMX}: 1.0 \mu \mathrm{g} \mathrm{mL} \mathrm{L}^{-1}, \mathrm{Na}_{2} \mathrm{CO}_{3}$. 3.0x $10^{-3} \mathrm{M}, \mathrm{TX}-114$; $0.5 \% \mathrm{CPT}$; $65^{\circ} \mathrm{C}$ and 20 min incubation time. For MCP; $0.88 \mu \mathrm{g} \mathrm{mL} \mathrm{L}^{-1} \mathrm{Na}_{2} \mathrm{CO}_{3} ; 1.0 \times 10^{-3} \mathrm{M}, \mathrm{TX}-114 ; 0.5 \%, \mathrm{CPT} ; 65^{\circ} \mathrm{C}$ and $20 \mathrm{~min}$ incubation time].

\subsubsection{Effect of Triton X-114 Amount}

Most studies confirm that the amount of an nonionic surfactant-type TX-114 as an extracting medium plays an important role for maximizing the extraction efficiency by minimizing the phase volume ratio $(\mathrm{Vs} / \mathrm{Va})$ and therefore improving the pre-concentration factor of the CPE procedure $[25,33]$. Therefore, the amount of TX-114 was investigated by varying the volume of $10 \% \mathrm{TX}-114$ between $(0.2-2.0 \mathrm{~mL})$ for AMX and (0.1-1.0 mL) for MCP. The results are presented in Figure 5. It was noticed that the absorbance values of AMX drug continued to increase dramatically and reached maximum at $1.0 \mathrm{~mL}$ of $10 \% \mathrm{TX}-144$ (i.e. $1.0 \% \mathrm{TX}-114$ in 10 $\mathrm{mL}$ solution), while there was a marginal increase in the absorbed values for MCP drug and reached maximum at 0.6 $\mathrm{mL}$ of $10 \% \mathrm{TX}-114$ (i.e. $0.6 \% \mathrm{TX}-114$ in $10 \mathrm{~mL}$ solution). These values were selected as optimal amount and used in the proposed methods for the detection of AMX and MCP.

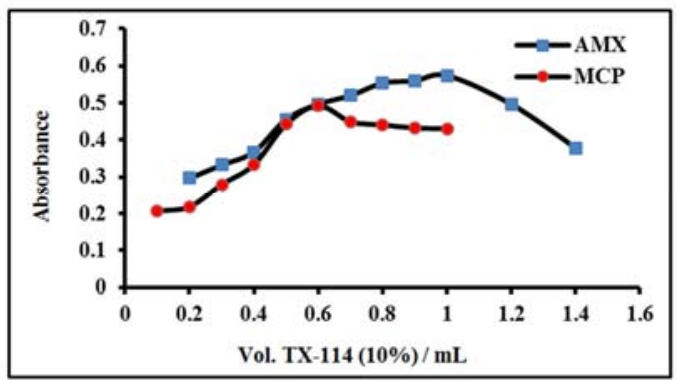

Figure 5. Effect of the TX-114 amount on absorbance and extractability of

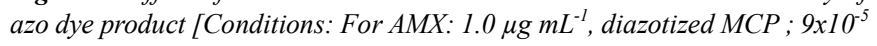

$\mathrm{M}, \mathrm{Na}_{2} \mathrm{CO}_{3} ; 3.0 \times 10^{-3} \mathrm{M}, \mathrm{CPT} ; 65^{\circ} \mathrm{C}$ and $20 \mathrm{~min}$ incubation time. For MCP; $0.88 \mu \mathrm{g} \mathrm{mL} \mathrm{L}^{-1}, \mathrm{AMX}$; $9.53 \times 10^{-6} \mathrm{M}_{\mathrm{Na}} \mathrm{Na}_{3} ; 1.0 \times 10^{-3} \mathrm{M}$, $\mathrm{CPT}$; $65^{\circ} \mathrm{C}$ and $20 \mathrm{~min}$ incubation time].

\subsubsection{Effect of Equilibration Temperature and Incubation Time}

The influence of these two parameters is considered of the most crucial steps in CPE, in order to ensure the efficient phase separation, which reflects certainly the magnitude of extraction efficiency of each target analyte. Figure 6 shows the variation on the absorption signal via varying the temperature between 25 to $70^{\circ} \mathrm{C}$ at 20 min incubation time for both drugs

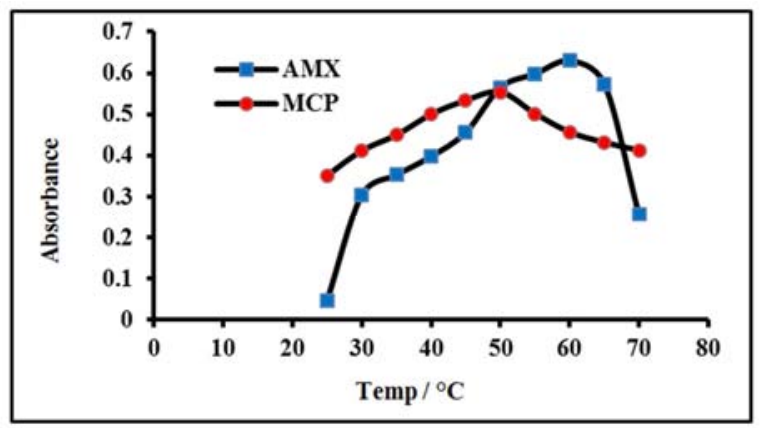

Figure 6. Effect of equilibration temperature on the absorbance and

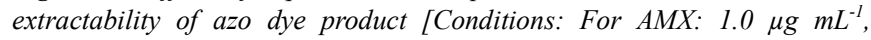
diazotized $\mathrm{MCP} ; 9 \times 10^{-5} \mathrm{M}, \mathrm{Na}_{2} \mathrm{CO}_{3} ; 3.0 \times 10^{-3} \mathrm{M}, \mathrm{TX}-114 ; 1.0 \%, 20 \mathrm{~min}$ incubation time. For $\mathrm{MCP} ; 0.88 \mu \mathrm{g} \mathrm{mL} \mathrm{L}^{-1}, \mathrm{AMX}$; $9.53 \times 10^{-6} \mathrm{M}, \mathrm{Na}_{2} \mathrm{CO}_{3}$; $1.0 \times 10^{-3} \mathrm{M}, \mathrm{TX}-114 ; 0.6 \%, 20 \mathrm{~min}$ incubation time].

which proved that the maximum absorption signal of both target analysts was achieved at 60 and $50{ }^{\circ} \mathrm{C}$ for AMX and $\mathrm{MCP}$ respectively because of high number of micelles formed in cloud point layer leading the entire transfer of the azo dye product into surfactant-rich phase that maximize the sensitivity. A significant decrease of the absorbance response was observed thereafter, probably due to the instability or dissociation of the azo dye product at higher temperature than optimal. 60 and $50^{\circ} \mathrm{C}$ were selected and used as optimal in the general CPE procedures of both analytes. Figure 7 illustrates the study of varying of incubation time from 5 to $40 \mathrm{~min}$ at optimum temperatures of both analytes. It was found that the incubation times of 25 and $20 \mathrm{~min}$ were quite enough for the maximum absorption signal of AMX and MCP in the azo dye product extraction respectively.

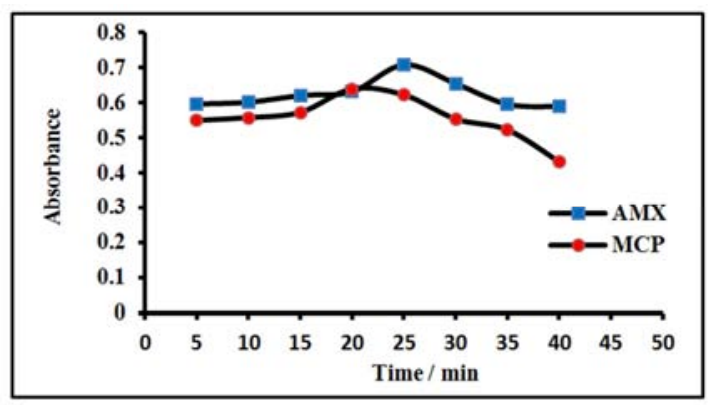

Figure 7. Effect of incubation time on absorbance and extractability of azo

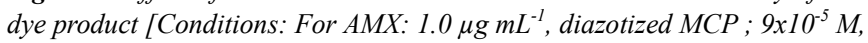
$\mathrm{Na}_{2} \mathrm{CO}_{3}$; $3.0 \times 10^{-3} \mathrm{M}, \mathrm{TX}-114 ; 1.0 \%, \mathrm{CPT} ; 60^{\circ} \mathrm{C}$. For $\mathrm{MCP} ; 0.88 \mu \mathrm{g} \mathrm{mL} \mathrm{L}^{-1}$, $\mathrm{AMX}$; $\left.9.53 \times 10^{-6} \mathrm{M}, \mathrm{Na}_{2} \mathrm{CO}_{3} ; 1.0 \times 10^{-3} \mathrm{M}, \mathrm{TX}-114 ; 0.6 \% \mathrm{CPT} ; 50{ }^{\circ} \mathrm{C}\right]$. 
Table 2 shows a summary for the best values of the study of the experimental variables for the direct determination of AMX drug and back- determination of MCP drug spectrophotometrically through the azo dye formation after CPE method.

Table 2. The summary of optimum experimental conditions for the extraction of azo dye product by CPE for both drug.

\begin{tabular}{llll}
\hline item & Variable & AMX & MCP \\
\hline 1 & $\mathrm{Na}_{2} \mathrm{CO}_{3}{ }^{*}$ & $3.0 \times 10^{-3} \mathrm{M}$ & $1.0 \times 10^{-3} \mathrm{M}$ \\
2 & diazotized MCP drug* & $9.0 \times 10^{-5} \mathrm{M}$ & - \\
3 & AMX drug $*$ & - & $9.53 \times 10^{-6} \mathrm{M}$ \\
4 & TX-114* & $1.0 \%$ & $0.6 \%$ \\
5 & Temperature & $60{ }^{\circ} \mathrm{C}$ & $50{ }^{\circ} \mathrm{C}$ \\
6 & Incubation time & $25 \mathrm{~min}$ & $20 \mathrm{~min}$ \\
7 & $\lambda_{\max }$ & 479 & 479 \\
\hline
\end{tabular}

*Final concentrations in $10 \mathrm{~mL}$ solution that carried out by CPE

\subsubsection{Order of Additions}

The effect of order for additions of the reagents on the absorbance of each analyte by the general CPE was tested. Table 3 shows that the best order of addition is the number 1 for both target analytes due to giving a highest absorption signal among the others.

Table 3. Effect of order of additions.

\begin{tabular}{lll}
\hline No. & Addition & $\begin{array}{l}\text { Absorbance at } \\
\lambda_{\text {max }}=\mathbf{4 7 9}\end{array}$ \\
\hline 1 & Analyte + reagent $+\mathrm{Na}_{2} \mathrm{CO}_{3}+\mathrm{TX}-114$ & 0.260 \\
2 & Analyte $+\mathrm{Na}_{2} \mathrm{CO}_{3}+$ reagent $+\mathrm{TX}-114$ & 0.037 \\
3 & Reagent $++\mathrm{Na}_{2} \mathrm{CO}_{3}+\mathrm{Analyte}^{\mathrm{TX}}-114$ & 0.044 \\
4 & Reagent + Analyte $+\mathrm{Na}_{2} \mathrm{CO}_{3}+\mathrm{TX}-114$ & 0.171 \\
\hline
\end{tabular}

\subsection{Structure of Azo Dye Product}

It was reported that the analysis of the dependence $\log D=f$ ( $\log \mathrm{C}_{\text {REAGENT }}$ ) allows calculating the composition of the azo dyes product by using the slope analysis method [34]. The results depicted in Figure 8 show that the slope for $\log \mathrm{D}$ as a function of $\log$ [Diazotized MCP] is equal to 1.846, indicating that the azo coupling reaction system between AMX and diazotized MCP in alkaline medium with ratio of 1:2 (AMX: Diazotized MCP) extracted into the surfactant-rich phase. Thus the most probable pathway for formation of the extracted azo dye product is preceded by two steps as shown in the Figure 9.

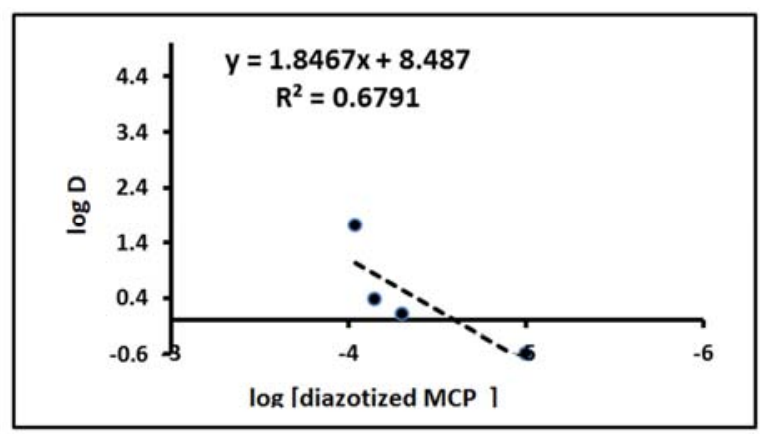

Figure 8. Slope analysis graph for the determination the composition of azo coupling product in the diazotization reaction $A M X$ with diazotized MCP.

\subsection{Validation of the Analytical Method}

The validation of the proposed method for the direct detection of AMX and back-determination of MCP in pharmaceutical samples was conducted via testing the linearity, sensitivity, limits of detection (LOD) quantitation (LOQ), accuracy and precision and other important parameters to achieve the acceptance criteria that applicable for the analysis of both drugs in the samples under study.

\subsubsection{Linearity}

Nine standard solutions of the drugs AMX and MCP were individually prepared in order to obtain a concentration range from $0.3-3.0 \mu \mathrm{g} \mathrm{mL}^{-1}$ and then subjected to the recommended CPE procedures under the optimized established conditions (Table 2). The graphical presentations of the absorbance plot obtained for AMX and MCP against the concentration of each analyte solution are given in the Figure 10 (a) and (b). The statistical evaluation for the two calibration curves reveals that the linear regression equations for both analytes were statistically valid. This because of the ratios (MSreg/MSerror) for 1 and 7 dof, larger than critical value $(F 1,7=5.59$ at $\alpha=0.05$ ), indicating that the predication based on the regression line is satisfactory as listed in Table 4.

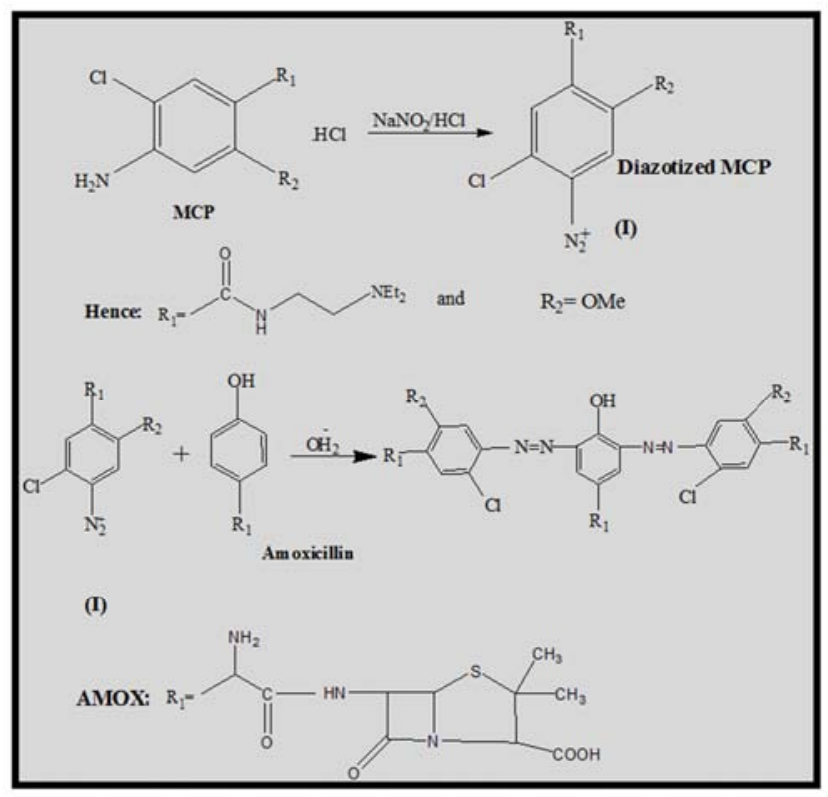

Figure 9. The probable reaction mechanism between $A M X$ and diazotized MCP in alkaline medium.

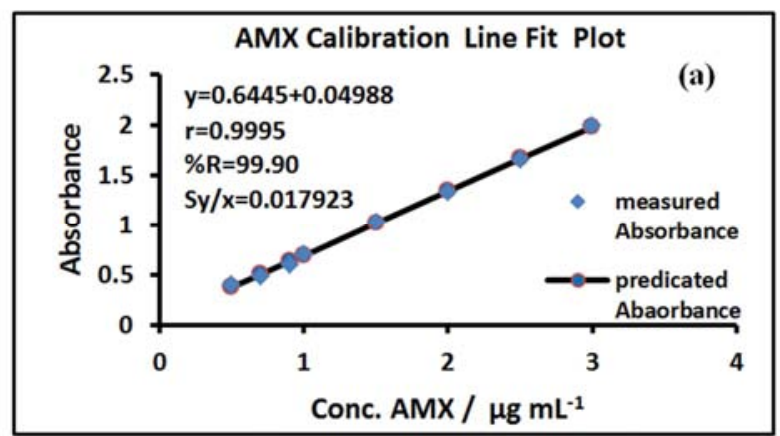




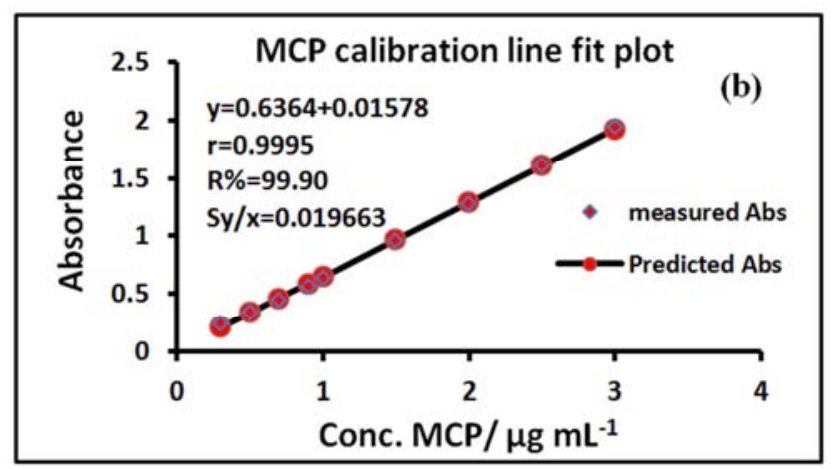

Figure 10. Calibration curves for (a) AMX and (b) MCP by the proposed method.

Table 4. Analysis of Variance of regression line for $A M X$ and $M C P$.

\begin{tabular}{|c|c|c|c|c|c|c|}
\hline Analyte & $\begin{array}{l}\text { Source } \\
\text { F (p-value) }\end{array}$ & dof & SS & MS & $\mathbf{F}$ & significance \\
\hline \multirow{3}{*}{ AMX } & Regression & 1 & 2.93096 & 2.93096 & 9124.79 & 0.000 \\
\hline & Residual Error & 7 & 0.00225 & 0.00032 & & \\
\hline & Total & 8 & 2.93321 & & & \\
\hline \multirow{3}{*}{ MCP } & Regression & 1 & 2.85722 & 2.85722 & 7390.24 & 0.000 \\
\hline & Residual Error & 7 & 0.00271 & 0.00039 & & \\
\hline & Total & 8 & 2.85993 & & & \\
\hline
\end{tabular}

Table 5. Statistical data and analytical figures of merits for AMX and MCP by. CPE-Spectrophotometry.

\begin{tabular}{|c|c|c|}
\hline Parameter & AMX & MCP \\
\hline Dye colour & Orange & Orange \\
\hline$\lambda_{\max }(\mathrm{nm})$ & 479 & 479 \\
\hline Regression equation (9 points) & $y=0.6445 x+0.0498$ & $y=0.6364 x+0.0158$ \\
\hline Standard deviation of regession line $\left(\mathrm{S}_{\mathrm{y} / \mathrm{x}}\right)$ & 0.0179223 & 0.019663 \\
\hline Correlation coefficient (r) & 0.9995 & 0.9995 \\
\hline Coefficient of determination $\left(\mathrm{R}^{2}\right)$ & 99.90 & 99.90 \\
\hline C.L. for the intercept $\left(a \pm t_{a}\right)$ at $95 \%$ & $0.0468 \pm 0.09551$ & $0.0158 \pm 0.02020$ \\
\hline Beer's law range $\left(\mu \mathrm{g} \mathrm{mL}^{-1}\right)$ & $0.3-3.0$ & $0.3-3.0$ \\
\hline Limit of Detection $\left(\mu \mathrm{g} \mathrm{mL}^{-1}\right)$ & 0.083 & 0.098 \\
\hline Limit of Quantitation $\left(\mu \mathrm{g} \mathrm{mL}^{-1}\right)$ & 0.29 & 0.31 \\
\hline Sandell's sensitivity $\left(\mu \mathrm{g} \mathrm{cm}^{-2}\right) \times 10^{-3}$ & 0.00155 & 0.00157 \\
\hline Molar absorptivity $\left(\mathrm{L} \cdot \mathrm{mol}^{-1} \cdot \mathrm{cm}^{-1}\right)$ & $2.35 \times 10^{5}$ & $2.25 \times 10^{5}$ \\
\hline Compsition of the colored product* & $1: 2$ & $1: 2$ \\
\hline $\mathrm{RSD} \%(\mathrm{n}=5)$ & 2.30 at $1.0 \mu \mathrm{g} \mathrm{mL}^{-1}$ & 0.029 at $1.50 \mu \mathrm{g} \mathrm{mL}^{-1}$ \\
\hline Preconcentration factor** & 33.3 & 50.0 \\
\hline Enrichment factor*** & 214 & 90.85 \\
\hline Recovery $(\%)^{* * * *}$ & $98.67 \pm 2.31$ & $100.33 \pm 5.19$ \\
\hline Extraction efficiency $(\% \mathrm{E})$ & 98.17 & 98.40 \\
\hline Distribution ratio (D) & 53.70 & 61.50 \\
\hline
\end{tabular}

*Slope analysis method ** Preconcentration factor was calculated the ratio of the original sample volume to that of extracted volume (of surfactant-rich phase) $* * *$ Enrichment factor was calculated experimentally by dividing the slop of calibration of the target analyte with CPE to the slope calibration of the target analyte without CPE.****in aqueous solution

\subsubsection{Detection, Quantitation Limit and Sensitivity}

The evaluation of these parameters was based on the regression line. Thus the limit of detection (LOD) and limit of quantitation (LOQ) are based on the standard deviation of the response (residual standard deviation; $\mathrm{S}_{\mathrm{y} / \mathrm{x}}$ ) and the slope of the calibration curve using the following equations; $\operatorname{LOD}=3 \sigma_{\mathrm{B}} / \mathrm{s}$; $\mathrm{LOQ}=10 \sigma_{\mathrm{B}} / \mathrm{s}$, where $\left(\sigma_{\mathrm{B}}\right)$ is the standard deviation from the regression line and (s) its slope. Based on the results of the calibration curve for AMX and MCP drugs, detection limits of 0.083 and $0.098 \mu \mathrm{g} \mathrm{mL}^{-1}$ were calculated, while LOQ's were found to be of 0.29 and $0.31 \mu \mathrm{g} \mathrm{mL}^{-1}$ (Table 5). These low detection limits might be due to obtaining high enrichment factors (214 and 90.85) of both drugs by the proposed method compared to traditional UV-Vis spectrophotometry. Further, 
good sensitivities in terms of molar absorptivity $(\varepsilon)$ for each target analyte were nearly equal and found to be of $2.35 \times 10^{5}$ and $2.25 \times 10^{5} \mathrm{~L} \cdot \mathrm{mol}^{-1} . \mathrm{cm}^{-1}$ for AMX and MCP respectively. Concerning the detection limit of AMX drug, the detection limit obtained in the proposed method was better than the reported methods using diazotization reaction (Table 6). Whilst for MCP drug, our findings turned out to be better than that obtained by some authors. But, it is not better than the remainder reports using different coupling reagents as shown in Table 7. In addition, the determination of two drugs sequentially by exploiting the same procedure itself is unique to the chemical analysis method compared with the earlier reported work published in the chemical literature, which focused on estimating on target analyte (Tables 6 and 7)

\subsubsection{Accuracy and Precision Study}

An approach according to three-point calibration with 1.0, 1.5 and $2.0 \mu \mathrm{g} \mathrm{mL}^{-1}$ for AMX and/or 0.7, 1.0 and $1.5 \mu \mathrm{g}$

Table 6. Reported methods for the determination of AMX by spectrophotometry after diazotization,oxidative coupling and charge transfer reactions.

\begin{tabular}{|c|c|c|c|c|}
\hline Coupling Reagent Used/ Reaction Type & $\begin{array}{l}\lambda_{\max } \\
(\mathbf{n m})\end{array}$ & $\begin{array}{l}\text { Linearity } \\
\left(\mu \mathrm{g} \mathrm{m}^{\mathrm{I}-1}\right)\end{array}$ & $\begin{array}{l}\text { LOD } \\
\left(\mu g \mathrm{~m}^{1-1}\right)\end{array}$ & Ref. \\
\hline Benzocain /diazotization & 455 & $2-16$ & 0.240 & 8 \\
\hline o-nitroaniline/ diazotization & 435 & $1-5$ & 0.125 & 9 \\
\hline p-nitroaniline/ diazotization & 478 & $0.5-100$ & 0.104 & 10 \\
\hline o-nitroaniline /diazotization & 435 & $25-400$ & 5.100 & 11 \\
\hline $\begin{array}{l}\text { p-amino benzoic acid } \\
\text { procain / diazotization }\end{array}$ & $\begin{array}{l}435 \\
450\end{array}$ & $\begin{array}{l}0.4-10 \\
0.4-14\end{array}$ & $\begin{array}{l}0.187 \\
0.192\end{array}$ & 12 \\
\hline Sulphanilic acid/ diazotization & 455 & $0.3-30$ & 0.150 & 13 \\
\hline 2,4- dinitrophenylhydrazine (DNPH) & 515 & $1-40$ & 0.230 & 35 \\
\hline 4-Aminoantipyrine /Oxidative coupling & 510 & $1-60$ & 0.173 & 36 \\
\hline N-bromosuccinamid (NBS)+ methylene blue/ oxidation & 663 & $5-50$ & - & 37 \\
\hline $\begin{array}{l}\text { 2, 4- dinitrophenylhydrazine/ } \\
\text { Oxidative Coupling }\end{array}$ & 520 & $4-33$ & 0.090 & 38 \\
\hline $\begin{array}{l}\mathrm{N}, \mathrm{N} \text {-dimethyl-p-phenylenediamine and potassium hexacyanoferrate (III)/ } \\
\text { Oxidative coupling }\end{array}$ & 600 & $\begin{array}{l}2-40 \\
10-70\end{array}$ & $\begin{array}{l}0.637 \\
4.900\end{array}$ & 39 \\
\hline Metol / Charge transfer & 620 & $5-60$ & 1.494 & 40 \\
\hline Metoclopramide hydrochloride/ diazotization & 479 & $0.3-3.0$ & 0.083 & This work \\
\hline
\end{tabular}

Table 7. Reported methods for the determination of of MCP.HCl by spectrophotometry after diazotization, oxidative coupling and charge transfer reactions.

\begin{tabular}{|c|c|c|c|c|}
\hline Coupling Reagent Used/ Reaction Type & $\begin{array}{l}\lambda_{\max } \\
(\mathrm{nm})\end{array}$ & $\begin{array}{l}\text { Linearity } \\
\left(\mu \mathrm{g} \mathrm{m}^{1-1}\right)\end{array}$ & $\begin{array}{l}\text { LOD } \\
\left(\mu \mathrm{g} \mathrm{m}^{\mathrm{l}-1}\right)\end{array}$ & Ref. \\
\hline dibenzoyl methane/ diazotization & 440 & - & - & 14 \\
\hline Aniline/ diazotization & 410 & $0.5-12.0$ & - & 15 \\
\hline Benzoylacetone/ diazotization & 437 & $0.8-13.2$ & 0.033 & 16 \\
\hline Imipramine hydrochloride/diazotization & 570 & $0.5-5.0$ & 0.014 & 17 \\
\hline p-dimethylaminocinnamaldehyde/ diazotization & 553 & $4-24$ & 1.120 & 18 \\
\hline Phenol/ diazotization & 463 & $1-20$ & 0.406 & 19 \\
\hline Diphenylamine / diazotization & 530 & $0.3-7.5$ & 0.220 & 21 \\
\hline 2,5-dimethoxyaniline (DMA) /diazotization & 486 & $0.1-12$ & 0.016 & 22 \\
\hline doxycycline hyclate /diazotization & 452 & $0.1-10$ & 0.012 & 23 \\
\hline Phenoxide / diazotization & 462 & $10-80$ & 3.700 & 24 \\
\hline malachite green in the presence of $0.01 \mathrm{M}$ chloramine- $\mathrm{T}$ and $2 \mathrm{M} \mathrm{H}_{2} \mathrm{SO}_{4}$, & 623 & $2-10$ & 0.087 & 41 \\
\hline Folin-Ciocalteu/ complex formation & 760 & Up to 100 & 2.000 & 42 \\
\hline 9-chloroacridine / oxidative coupling & 470 & $2-50$ & 0.368 & 43 \\
\hline Amoxicillin /diazotization & 479 & $0.3-3.0$ & 0.098 & This work \\
\hline
\end{tabular}

$\mathrm{mL}^{-1}$ of MCP standard solutions were chosen in this validation study. All these standard solutions were spiked with accurate amounts of drug matrix solution containing $1.0 \mu \mathrm{g}$ $\mathrm{mL}^{-1}$ for AMX (PAN capsule, France) and MCP (MCP Hameln injection, Germany) followed the recommended CPE procedure and each solution was measured five times. The results summarized in Tables 8 and 9 have revealed that a satisfactory accuracy in terms of percent recoveries obtained were within average of $97.77 \pm 1.72 \%$ for AMX and $98.20 \pm$ $1.95 \%$ for MCP with the $95 \%$ confidence interval ranges from $96.05 \%$ to $100.15 \%$, concluding the theoretical value of $100 \%$ is included. It confirmed that the systematic errors were relatively absent, concluding the presence of matrix constituents of these samples had no appreciable effect on the determination of these analytes as the requirement for mean recovery of this validation study is met. Thus the study of interferences from the drugs matrices is unnecessary. Meanwhile, each spiked sample was repeated five times for precision testing in terms of $\% \mathrm{RSD}$ and found in the range of $2.35-4.35 \%$ for AMX and $0.20-3.43 \%$ for MCP, indicative a good precision of the method. 
Table 8. Accuracy and precision test for AMX capsule by proposed method.

\begin{tabular}{|c|c|c|c|c|c|}
\hline $\begin{array}{l}\text { AMX } \\
\text { Taken } \\
\left(\mu \mathrm{g} \mathrm{mL}^{-1}\right)\end{array}$ & 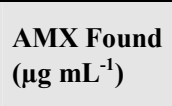 & $\begin{array}{l}\text { Recovery } \\
(\%)\end{array}$ & $\begin{array}{l}\text { Mean } \operatorname{Rec} \% \pm \text { C.L } \\
\text { at } 95 \%\end{array}$ & Er\% & $\begin{array}{l}\text { RSD\% } \\
(n=5)\end{array}$ \\
\hline Sample & 1.0 & - & \multirow{4}{*}{$97.77 \pm 1.72$} & & \\
\hline 1.0 & 1.94 & 97.00 & & -3.00 & 4.35 \\
\hline 1.5 & 2.45 & 98.00 & & -2.00 & 3.67 \\
\hline 2.0 & 2.95 & 98.33 & & -1.67 & 2.35 \\
\hline
\end{tabular}

Table 9. Accuracy and precision test for MCP in German Ampoule.

\begin{tabular}{|c|c|c|c|c|c|}
\hline $\begin{array}{l}\text { MCP } \\
\text { Taken } \\
\left(\mu \mathrm{g} \mathrm{mL}^{-1}\right)\end{array}$ & $\begin{array}{l}\text { MCP Found } \\
\left(\mu \mathrm{g} \mathrm{mL} \mathbf{~}^{-1}\right)\end{array}$ & $\begin{array}{l}\text { Recovery } \\
(\%)\end{array}$ & $\begin{array}{l}\text { Mean R\% } \pm \text { C.L } \\
\text { at } 95 \%\end{array}$ & Er\% & $\begin{array}{l}\text { RSD\% } \\
(n=5)\end{array}$ \\
\hline sample & 1.0 & - & \multirow{4}{*}{$98.20 \pm 1.95$} & & \\
\hline 0.7 & 1.693 & 99.0 & & -1.0 & 3.43 \\
\hline 1.0 & 1.945 & 95.5 & & -0.5 & 1.26 \\
\hline 1.5 & 2.516 & 101.1 & & 1.1 & 0.20 \\
\hline
\end{tabular}

\section{i. Determination of $A M X$ drug in pharmaceuticals}

The proposed method was applied to the AMX determination in five selected pharmaceutical drugs (one capsule and four vials) produced in different countries containing $500 \mathrm{mg}$ amoxicillin as an active ingredient. The samples were prepared as stated in experimental section from which each sample was subjected to the recommended CPE and AMX drug detected spectrophotometrically at $\lambda_{\max }$ of 479 $\mathrm{nm}$. The results are presented in Table 10. The results revealed that the calculated t-values for AMX determination using MCP drug as diazotization agent in different pharmaceuticals are less than t-tabulated (4.303) at 95\% confidence interval and (n-1) degrees of freedom, so the null hypothesis Ho is maintained, concluding there is no evidence for systematic and random errors at the $95 \%$ confidence level and accordingly manufacturer's claims can be accepted.

\subsubsection{Applications}

Table 10. Determination of AMX drug in tablet and injection samples by the proposed method and statistical comparison with quoted values.

\begin{tabular}{|c|c|c|c|c|}
\hline Commercial name, and content & $\begin{array}{l}\text { Practical } \\
\text { Content (mg) } \\
\text { (proposed method) }\end{array}$ & $\begin{array}{l}t=(x-\mu) \sqrt{n} / s \\
\text { proposed method Vs. Claimed value at } 95 \% \text { C.I. }\end{array}$ & $\% \mathbf{E}_{\text {rel }}$ & $\begin{array}{l}\text { \%RSD } \\
(n=3)\end{array}$ \\
\hline \multirow{4}{*}{$\begin{array}{l}\text { Amoxicillin, capsule (Iranian) farabi } \\
\text { pharmaceutical,500mg }\end{array}$} & 492 & \multirow{4}{*}{$\mathrm{t}_{\mathrm{cal}}=\mathbf{1} .271 .27<4.303$} & \multirow{4}{*}{-1.47} & \multirow{4}{*}{2.03} \\
\hline & 503 & & & \\
\hline & & & & \\
\hline & $492.67 \pm 10.02$ & & & \\
\hline \multirow{2}{*}{$\begin{array}{l}\text { Amoxicillin - AMITRON } \\
\text { (Barcelona)LDP Laboratorios } \\
\text { TORLAN S.A (Spain), vial } 500 \mathrm{mg}\end{array}$} & $\begin{array}{l}488.0 \\
492.0 \\
487.0\end{array}$ & \multirow[t]{2}{*}{$\mathrm{t}_{\mathrm{cal}}=\mathbf{3 . 9 3} 3.93<4.303$} & \multirow[t]{2}{*}{-2.73} & \multirow[t]{2}{*}{1.24} \\
\hline & $486.33 \pm 6.03$ & & & \\
\hline \multirow{2}{*}{$\begin{array}{l}\text { Amoxicillin } \\
\text { (PANPHARMA S.A.,France), vial } \\
500 \mathrm{mg}\end{array}$} & $\begin{array}{l}498.0 \\
483.7 \\
493.8\end{array}$ & \multirow[t]{2}{*}{$\begin{array}{l}\mathrm{t}_{\mathrm{cal}}=1.92 \\
1.92<4.303\end{array}$} & \multirow[t]{2}{*}{-1.61} & \multirow[t]{2}{*}{1.49} \\
\hline & $491.93 \pm 7.35$ & & & \\
\hline \multirow{2}{*}{$\begin{array}{l}\text { Amoxicillin- cox } \\
\text { PHARMACEUTICAL LTD } \\
\text { (England ), vial } 500 \mathrm{mg}\end{array}$} & $\begin{array}{l}491.5 \\
485.0 \\
478.0\end{array}$ & \multirow[t]{2}{*}{$\begin{array}{l}\mathrm{t}_{\mathrm{cal}}=\mathbf{3 . 8 9} \\
3.89<4.303\end{array}$} & \multirow[t]{2}{*}{-3.03} & \multirow[t]{2}{*}{1.39} \\
\hline & $484.83 \pm 6.75$ & & & \\
\hline \multirow[t]{2}{*}{$\begin{array}{l}\text { Amoxicillin Pharma Roth } \\
\text { (Germany), vial } 500 \mathrm{mg}\end{array}$} & $\begin{array}{l}484.0 \\
489.3 \\
498.2\end{array}$ & \multirow[t]{2}{*}{$\begin{array}{l}\mathrm{t}_{\mathrm{cal}}=\mathbf{2 . 2 9} \\
2.29<4.303\end{array}$} & \multirow[t]{2}{*}{-1.90} & \multirow[t]{2}{*}{1.46} \\
\hline & $490.50 \pm 7.18$ & & & \\
\hline
\end{tabular}

\section{ii. Back-Determination of MCP drug in pharmaceuticals}

Three selected pharmaceuticals from different producers in the form of ampoules containing $10 \mathrm{mg}$ per $2 \mathrm{~mL}$ of active MCP medicament were examined to test the applicability of proposed method using AMX as mediating agent. Each sample was simply diluted with water to obtain an appropriate concentration from which it was subjected to the recommended CPE procedure and MCP drug determined spectrophotometrically at at $\lambda_{\max }$ of $479 \mathrm{~nm}$. The statistical analysis results exhibited in Table 11 proved again that the calculated t-values for MCP determination in different pharmaceuticals are less than t-tabulated (4.303) at 95\% confidence interval and (n-1) degrees of freedom, so the null hypothesis Ho is maintained, concluding there is no evidence for systematic and random errors at the $95 \%$ confidence level and accordingly manufacturer's claims can be accepted.

\section{Conclusions}

This work presents a new mode of chemical analysis by the combined CPE-spectrophotometry compared with our previous published works, for the mutual determination of the two drugs that participate in chemical derivatization via using azo coupling reaction. The proposed method gave distinct features which appeared the acceptable analytical figures of merit and high reliability compared with other published methods (Tables 6 and 7). Furthermore, the prospect advantages of the established method are time-saving, reducing the amount of reagents used as well as minimizing analyst effort. However, the shortcoming of this method lies in difficulty of estimating these drugs in biological samples (blood and urine) because the presence of some of the 
constituents in these matrices may be involved in the azo-coupling reaction which leads to the deterioration of the sensitivity and detection limit of the drugs under study.
However, this method can be easily applied to environmental samples, particularly waste water flowing from the medicaments industries.

Table 11. Determination of MCP drug in the injection samples by the proposed method and statistical comparison with quoted values.

\begin{tabular}{|c|c|c|c|c|}
\hline Commercial name, and content & $\begin{array}{l}\text { Practical Content }(\mathrm{mg} / 2 \mathrm{~mL}) \\
\text { (proposed method) }\end{array}$ & $\begin{array}{l}t=\overline{(x}-\mu) \sqrt{n} / \mathrm{s} \\
\text { proposed method Vs. Claimed value at } 95 \% \text { C.I. }\end{array}$ & $\% \mathbf{E}_{\text {rel }}$ & $\begin{array}{l}\% \text { RSD } \\
(\mathrm{n}=3)\end{array}$ \\
\hline $\begin{array}{l}\text { Metoclopramide - METAMID } \\
\text { injection ((IBN HAYYAN PHARM } \\
\text { Syrian), } \\
10 \mathrm{mg} / 2 \mathrm{~mL}\end{array}$ & $\begin{array}{l}9.64 \\
9.95 \\
9.66 \\
9.75 \pm 0.173\end{array}$ & $\begin{array}{l}\mathrm{t}_{\mathrm{cal}}=2.50 \\
2.50<4.303\end{array}$ & -2.5 & 1.77 \\
\hline $\begin{array}{l}\text { Metoclopramide, injection (GLAND } \\
\text { PHRMA LIMITED, } \\
\text { Indian), } 10 \mathrm{mg} / 2 \mathrm{~mL}\end{array}$ & $\begin{array}{l}9.64 \\
9.84 \\
10.0 \\
9.83 \pm 0.180\end{array}$ & $\begin{array}{l}\mathrm{t}_{\mathrm{cal}}=1.66 \\
1.66<4.303\end{array}$ & -1.7 & 1.83 \\
\hline $\begin{array}{l}\text { Metoclopramide - injection } \\
\text { (hamelnpharmaceuticals gmbh Langes } \\
\text { Feld } 13 \text { Germany ), } 10 \mathrm{mg} / 2 \mathrm{~mL}\end{array}$ & $\begin{array}{l}9.90 \\
9.54 \\
10.1 \\
9.85 \pm 0.284\end{array}$ & $\begin{array}{l}\mathrm{t}_{\mathrm{cal}}=0.94 \\
0.94<4.303\end{array}$ & -1.5 & 2.88 \\
\hline
\end{tabular}

\section{References}

[1] Z. A-A. Khammas, and N. S. Mundir, "Cloud point extraction spectrophotometric method for mutual determination of Norfloxacin and Iron (III) in human serum and drug formulations," Chem. Sci. Transactions, 4 (2), pp. 483-497, 2015

[2] Z. A-A. Khammas and R. A. Rashid," Mutual determination of Trifluoperazine Hydrochloride and Vanadium (V) ions in real matrices by Visible Spectrophotometry after cloud point extraction", Science Journal of Analytical Chemistry, 3 (5), pp.61-70, 2015

[3] Z. A-A. Khammas and R. A. Rashid," Visible spectrophotometric analysis for the mutual determination of doxycycline hydrochloride and iron in real samples after cloud point extraction”, Int. J. Chem. Sci., 14 (2), pp. 955-977, 2016

[4] M. J.O. Neil, The Merck Index. An Encyclopaedia of Chemicals, Drugs and Biologicals. $14^{\text {th }}$ ed. New Jersey. Published by Merck Research Laboratories, Division of Merck and Co. Inc. Whitehouse station, p.313 (2006)

[5] British Pharmacopoeia (Her Majesty's Stationary Office, London. 2009) [2] United States Pharmacopeia XXXII, National Formulary XXVII, US Pharmacopeial Convention, (Rockville, Maryland (2008)

[6] C. P. Page, M. J. Curtis, M. C. Sutter, M. J. A. Walker,.and B. B.Hoffman, Farmacología Integrada (Ed. Harcourt. España. (1998)

[7] "Interaction between Amoxicillin and Metoclopramide", https://treato. com/Amoxicillin,Metoclopramide/? $\mathrm{a}=\mathrm{s}$, free online website

[8] S. M. El-Ashry, F. Belal, M. M. El-Kerdawy, and,D. R. El Wasseef," Spectrophotometric determination of some phenolic antibiotics in dosage forms", Mikrochim. Acta,135, pp. $191-196,2000$

[9] S. H. Hesham," selective spectrophotometric determination of phenolic-lactam antibiotics in pure forms and in their pharmaceutical formulations", Anal. Chim. Acta, 515, pp. 333341,2004
[10] M. Q. H. Al-Abachi, and H. Hadi," Flow injection spectrophotometric determination of amoxicillin in pharmaceutical samples by coupling with diazotized p-nitroaniline", Iraqi. J. Mark. Rec. Cons. Protection, 1 (1), pp.105-119,2009

[11] S. K.B. Freitas, V. L. da Silva, A. N. Araújo, B. S.M. Montenegro, B. F. Reis, and A. P. S. Paim.," Multicommuted flow analysis method for the photometric determination of amoxicillin in pharmaceutical formulations using a diazo coupling reaction", J. Braz. Chem. Soc., 22, (2), pp. 279-285, 2011

[12] W. A. Al-Uzri, "Spectrophotometric determination of amoxicillin in pharmaceutical preparations through diazotization and coupling reaction”, Iraqi J. Sci., 53 (4), pp. 713-723,2012

[13] Qader, H. A. and Fakhri, N. A., "Spectrophotometric determination of amoxicillin in pure and pharmaceutical dosage forms", Ibn Al-Haitham Journal for Pure and Applied Science, 28 (3), 1-11 (2015)

[14] H. D. Revanasiddappa and B. Manju, "A spectrophotometric method for the determination of metoclopramide $\mathrm{HCl}$ and dapsone", J. Pharm. Biomed. Anal., 25 (3-4), pp. 631-637,2001

[15] J. Shah, M. Rasul Jan, M. Azam Khan and S. Amin, " Spectrophotometric determination of metoclopramide in pharmaceutical preparations", J Anal. Chem., 60 (7), pp. 633-635,2005

[16] A. A. Omran, "Individual and simultaneous spectrophotometric determination of dapsone and metoclopramide $\mathrm{HCl}$ in pharmaceutical dosage forms and synthetic binary mixtures", Chem. Pharm. Bull. 53 (11),pp.1498-1501,2005

[17] H. D. Revanasiddappa and M. A. Veena, "Sensitive spectrophotometric sdetermination of metoclopramide hydrochloride and dapsone in bulk sample and dosage forms', ScienceAsia, 32, pp. 319-321,2006

[18] O. Guzel and A. Salman, " Spectrophotometric determination of drugs having primary amione group with p-dimethylaminocinnamaldehyde", Turkish J. Pharm. Sci., 4 (1), pp. $31-39,2007$ 
[19] R. Sinan and S. S. Abed, "Spectrophotometric determination of metoclopramide hydrochloride in tablets by diazotization and coupling reaction with phenol”, Iraqi J Sci., 50 (2), pp. $136-143,2009$

[20] L. A. Sarsam, S. A. Mohammed and K. M. Al-Abbasi, "Spectrophotometric determination of metoclopramide hydrochloride in pharmaceutical preparations using diazotization reaction”, Raf. J. Sci., 22 (.3), pp. 76- 88, 2011

[21] O. Z. Devi, K. Basavaiah, V. K.B. Vinay and H. D. Revanasiddappa,H. D., " Determination of metoclopramide hydrochloride in pharmaceuticals and spiked human urine through diazotization reaction", J. Food and Drug Anal., 20 (2), pp. 454-463, 2012

[22] A. A. Jawad, and H. K. Kasim, "Spectrophotometric determination of metoclopramide hyderchloride in bulk and pharmaceutical preparations by diazotization- coupling reaction”, Int. J. Pharm. Pharm. Sci.,5 (3), pp. 294-298,2013

[23] A. N. Alshirifi and M. H.Abbas "New pectrophotometric method for the determination of metoclopramide hydrochloride in pharmaceutical preparations based on coupling with doxycycline hyclate", Int. J. Chem. Sci.: 13 (3), pp. 1093-1108,2015

[24] M. M. Ibrahim, M. M. Ahmed, Y. A. Al-Amien and A. M. Daf-Allah, "Development and validation of colorimetric method for analysis of metoclopramide hydrochloride in bulk and pharmaceutical dosage form using visible spectroscopy", Int. J. Innov. Pharm. Sci. Res., 3 (11), pp. 1558-1568, 2015

[25] Z. A-A. Khammas and N. S. Mubdir, "An eco-friendly method for extraction and determination of ciprofloxacin in blood serum and pharmaceuticals", Science Journal of Analytical Chemistry, 2 (5),pp. 47-54, 2014

[26] A.B. Tabrizi, “A cloud point extraction-spectrofluorimetric method for determination of thiamine in urine", Bull. Korean Chem. Soc., 27, pp. 1604-1608,2006

[27] A. B. Tabrizi, "Determination of mefenamic acid in human urine by means of two spectroscopic method by using cloud point extraction methodology as a tool for treatment of samples", Bull. Korean Chem. Soc., 27, pp. 1780-1784, 2011

[28] A. B. Tabrizi and M. Harasi, "Applying cloud coint extraction technique for the extraction of oxazepam from human urine as color or fluorescent derivative prior to spectroscopic analysis methods", Drug Testing and Analysis, 4,pp. 145-150,2012

[29] Minitab version 17, Minitab Inc., State College, PA, USA), 2014

[30] A. N. Obedagha and R. N. Aljarah, "Development of spectrophotometric method for the determination of Metoclopramide. $\mathrm{HCl}$ in pharmaceutical preparations", Raf. J. Sci., 25 (2), pp. 10-21, 2014

[31] S. S. Abed," Flow injection analysis (FIA) for some organic drug compounds (Spectrophotometric and Kinetic Studies)", Ph. D thesis, University of Baghdad, 2012

[32] M. Q. Al-Abachi, S. S. Mohmmed and A. J. Hadi," The spectrophotometric determination of Famotidine drug via coupling with diazotized metochlopramide hydrochloride", Baghdad Science Journal, 12 (4),pp. 730-739, 2015

[33] J. L. Manzoori, and G. Karim-Nezhad," Development of a cloud point extraction and preconcentration method for $\mathrm{Cd}$ and $\mathrm{Ni}$ prior to flame atomic absorption spectrometric determination," Anal. Chim. Acta, 521, pp. 173-177, 2004

[34] Astrid Gojmerac Ivsic and Biserka Tamhina, "Extraction and Formation of Iron (III) Thiocyanate Complexes: Application for Spectrophotometric Determination of Iron", Croatica Chemica Atcta, 76 (4,) pp. 323-328,2003

[35] M. Q. Al-Abachi and S. Subhi, "Flow injection-spectrophotometric determination of phenylephrine hydrochloride and amoxicillin trihydrate in pharmaceutical preparations", Journal of Al-Nahrain University, 16 (1), pp.24-24, 2013

[36] M. Q. Al-Abachi and H. Hadi, "Flow injectionspectrophotometric determination of amoxicillin based on its oxidative condensation with 4-aminoantipyrine", Iraqi Journal of Science, 50 (1), pp. 8 - 15, 2009

[37] N. S. Othman and R. S. AL-Saffar, "Spectrophotometric determination of amoxicillin in pharmaceutical preparations", International Journal of Enhanced Research in Science Technology and Engineering, 4 (6)pp: (167-173),2015

[38] P. Nagaraja and A. K. Shrestha, "Spectrophotometric method for the determination of drugs containing phenol group by using 2, 4- Dinitrophenylhydrazine", E-Journal of Chemistry, 7 (2), pp. 395-402, 2010

[39] M. Q. Al-Abachi, H. Haddi and A. M. Al-Abachi," Spectrophotometric determination of amoxicillin by reaction with $N, N$-dimethyl- $p$-phenylenediamine and potassium hexacyanoferrate (III)", Anal. Chim. Acta, 554 (1-2), pp. 184189,2005

[40] M. Q. Al-Abachi and H. Hadi," A developed spectrophotometric determination of amoxicillin forms via charge-transfer reaction with phenol Journal of Al-Nahrain University, 10 (2), pp.1-6, 2007

[41] M. J. Solanki1, E. V. S. Subrahmanyam, and A. R. Shabaraya," Development of new analytical method and its validation for the determination of metoclopramide hydrochloride in bulk and marketed formulation" Research Journal of Pharmaceutical, Biological and Chemical Sciences, 4 (4), pp. 245-251, 2013

[42] M. deSouza Silva, L. M. F. S. Saraiva, J. L. M. Santos and J. F. C. Lima," Sequential injection spectrophotometric determination of metoclopramide in pharmaceutical preparations", Spectrosc. Lett., 40, pp. 51-61, 2007

[43] T. N. Al-Sabha, M. T. Al-Obaidi and T. S. Al-Ghabsha," Colorimetric determination of metoclopramide hydrochloricde and tranexamic acid using 9-chloroacridine reagent", Eur. Chem. Bull., 4 (5), pp. 234-239, 2015

[44] N. S. Othman, H. Sh. Mahmood, N. A. Khaleel, "Spectrophotometric determination of metoclopramide hydrochloride in pharmaceutical preparations via oxidative coupling reaction", Tikrit Journal of Pure Science, 16 (4),89-95,2011 